\title{
Assessing a Mercury Affected Area from Small-scale Gold Mining in Poboya, Central Sulawesi, Indonesia
}

\author{
Mega M. Sari ${ }^{1, *}$, Takanobu Inoue ${ }^{1}$, Yoshitaka Matsumoto $^{2}$, Kuriko Yokota ${ }^{1}$, Isrun Isrun ${ }^{3}$ \\ ${ }^{1}$ Department of Architecture and Civil Engineering, Toyohashi University of Technology, Japan \\ ${ }^{2}$ Department of Civil Engineering, Toyota National College of Technology, Japan \\ ${ }^{3}$ Department of Agriculture, Tadulako University, Indonesia
}

Copyright $(2016$ by authors, all rights reserved. Authors agree that this article remains permanently open access under the terms of the Creative Commons Attribution License 4.0 International License

\begin{abstract}
Poboya, Central Sulawesi is one of the primary sites used for small-scale gold mining activities in Indonesia. Poboya consumes 200-500 kg of mercury/day by amalgamation. Palu, the capital city of Central Sulawesi, is a city with a population of 0.35 million people and located around $11 \mathrm{~km}$ away from the edge of a small-scale gold mining area in Poboya. Fifteen samples of upper layer soil and fifteen samples of plant (Calotropis gigantean) were taken along the road that connects Poboya to Palu, at every $500 \mathrm{~m}$. Mercury concentration in the soil samples showed a gradual decrement as the distance from Poboya became greater. The plant samples also revealed a similar trend to the soil samples. The highest concentration of mercury in the soil was found at Poboya-i.e. $17.62 \mathrm{ng} / \mathrm{mg}$, and the concentration of mercury in Calotropis gigantean grown at Poboya was $6.5 \mathrm{ng} / \mathrm{mg}$. Based on the soil samples and pollution index, the data showed that the research area had heavy pollution levels up to $4 \mathrm{~km}$. Moreover, the transfer factor was in the range of 0.13-3.44 at distances of 0-4 km, respectively.
\end{abstract}

Keywords Calotropis Gigantean, Indonesia, Small-scale Gold Mining, Soil, Total Mercury

\section{Introduction}

Mercury is a global pollutant, persistent and naturally exists in the environment $[1,2,3,4]$. Mercury spreads in several forms, such as metallic mercury $\left(\mathrm{Hg}^{0}\right)$, divalent mercury $\left(\mathrm{Hg}^{++}\right)$and methylmercury $\left(\left(\mathrm{CH}_{3} \mathrm{Hg}\right)^{+}\right)[5,6,7,8]$. In Asia, mercury is mainly released from anthropogenic sources $[1,3,9]$ with the highest contributors being artisanal and small-scale gold mining which reached $38-54 \%$ of total global anthropogenic mercury emissions in 2010 $[3,10,11,12]$. The most often used method to extract gold from ore is the simple mercury amalgamation method $[11,13,14,15]$. Metallic mercury, released from gold amalgam burning, has spread across a wide area Cairns et al[1] and deposits on aquatic and land areas Liu et al[10]. Additionally, more than $98 \%$ of $\mathrm{Hg}^{0}$ formed diffused into the atmosphere $[4,10,16]$. Mercury from atmosphere is perennial and is more easily absorbed in the soil than into an aquatic environment and a high concentration of mercury in the soil, exceeding the ability of the soil to eliminate mercury, causes soil pollution $\mathrm{Xu}$ et al[17]. Moreover, an excess concentration in the soil transfers to surrounding environmental media Ministry of the Environment[20], such as plants. It is also possible that mercury can robustly transmit to plants through absorption by the plant's breathing apparatus $[5,10,18,19]$.

Indonesia, as a country located in east and southeast Asia, is using mercury for artisanal and small-scale gold mining UNEP[21]. During 1999 to 2002, Indonesia imported nine tons of mercury per year for mining usage Iqbal and Inoue[22], however, this value was different from the import rate of mercury in 1999 which was 129 tons Veiga et al[15], before the implementation of a mercury ban for industrial use in relation to the Indonesian Government Regulation No. 74/2001 Veiga et al[15]. However, mercury has mainly been released into the atmosphere, aquatic and land from small-scale gold mining in Indonesia. It has been reported that 70 tons of mercury is released into the environment annually Sharma[23]. Even more, another source reported that 100-150 tons of mercury is discharged per year $[15,24]$. The spread of mercury released into the atmosphere also causes contamination of surrounding areas besides the initial area Cairns et al[1]. Boening[25] reported that a high mercury concentration-i.e. $0.2 \mathrm{mg} / \mathrm{kg}$ was found in vegetation up to $25 \mathrm{~km}$ from a mining area in Spain. Based on that research, Palu was assumed as a contaminated area due to gold mining activities in Poboya, Central Sulawesi, Indonesia. The distance of Palu and Poboya is about $11 \mathrm{~km}$.

The main objective of this research is to assess the affected area from the edge of a gold mining area (Poboya) to the center of the city (Palu) of mercury contamination by small-scale gold mining using soil and plant. 


\section{Materials and Methods}

\subsection{Study Area}

This research was undertaken in Central Sulawesi, Indonesia. Poboya is one of the primary sites for small-scale gold mining activities in Indonesia, having 35000 miners working in an area of 7000 hectares [26,27]. It commenced operation in 2009 Albasar et al [28]. Poboya has high levels of gold mining and contributes around 200-500 kg/day of mercury through gold mining processes into the environment Ismawati et al[27]. This present condition makes Indonesia the second highest country globally in the level that it releases mercury into the environment [15,27]. Palu city was assumed as one of the areas that possibly may be impacted by mercury due to the gold mining site in Poboya because Palu city is located around $11 \mathrm{~km}$ away from Poboya. Palu city is the capital city of Central Sulawesi, Indonesia, which is also the center of community activities and has a population of 0.35 million people.

\subsection{Sampling}

The research was conducted to observe the total mercury concentration (THg) in Poboya, Central Sulawesi, Indonesia in October 2014 (see Figure 1). There were two types of samples; soil and plant. Firstly, soil samples were taken at regular intervals, at every $500 \mathrm{~m}$ up to $7 \mathrm{~km}$ from the edge of a small-scale gold mining area in Poboya to Palu, where the surrounding areas included settlements, and the sampling points are shown in Fig. 2. The $1^{\text {st }}$ sampling point was located $0 \mathrm{~m}$ from the edge of the small-scale gold mining area, and the $2^{\text {nd }}$ one was at a distance of $500 \mathrm{~m}$ from the $1^{\text {st }}$ sampling point. The last sampling point was the $15^{\text {th }}$ sampling point, which was located approximately $7 \mathrm{~km}$ from the initial one (see Figure 2). So, approximately 15 soil samples were collected. A 50 gram sample of soil for each sampling point was taken from the topsoil layer. The soil samples were placed in $50 \mathrm{ml}$ polypropylene bottles and sealed tightly using transparent tape.

Secondly, the plant sample taken was Calotropis gigantea, a local plant, which spreads across the landscape of Central Sulawesi. The vegetative structures (leaves) of Calotropis gigantea were used to represent the total mercury in plant sample. The quantity of plant samples (leaves) were cleaned using distilled water and kept in sealed bags. The plant samples were finely chopped before being used for laboratory analysis. Similar to the soil samples, the plant samples were taken at 15 sites spaced $500 \mathrm{~m}$ apart from the mining site to downtown, Poboya to Palu.

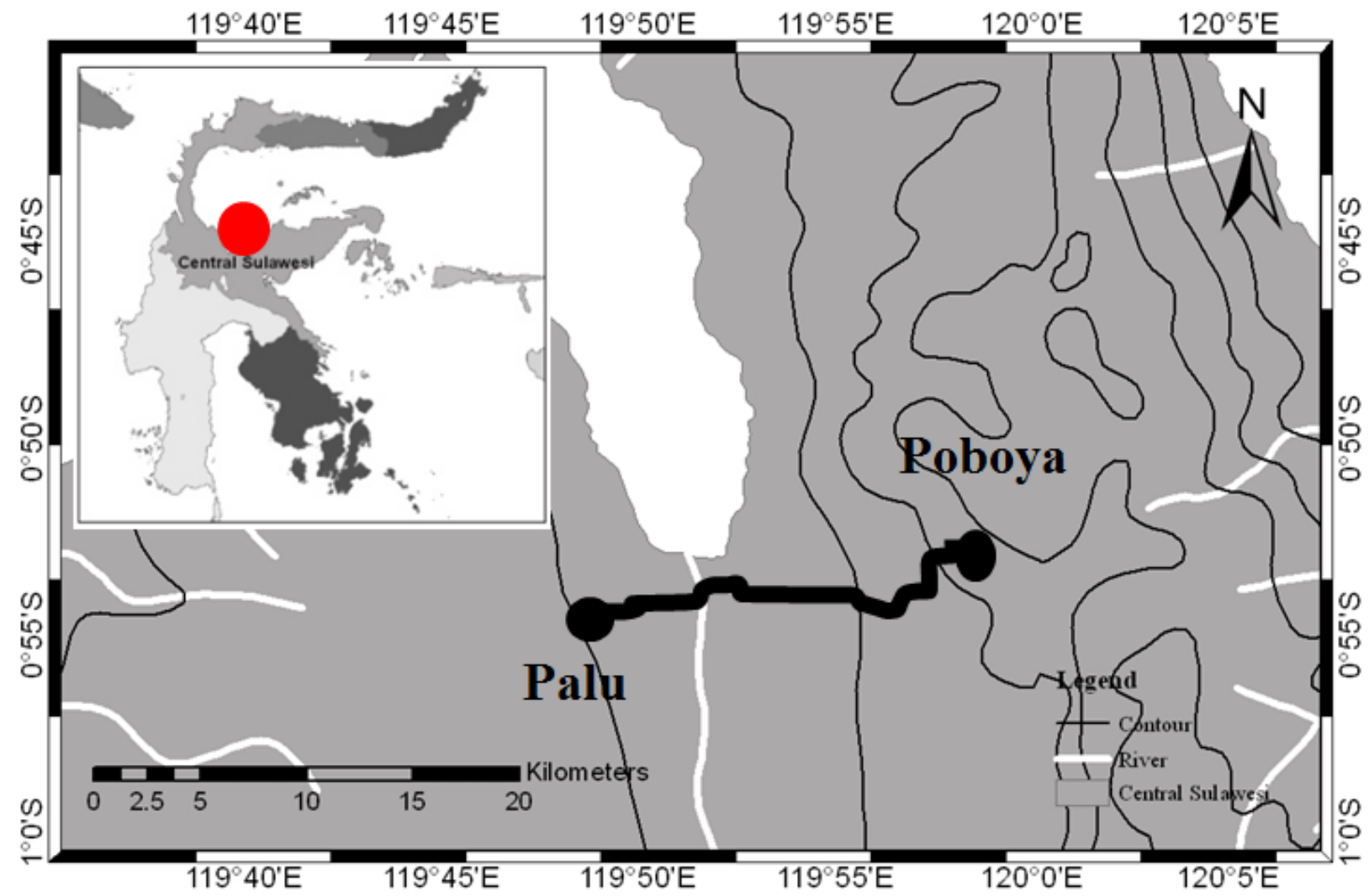

Figure 1. Study area 


\author{
Settlement \\ O = soil sample \\ $\mathbb{W}$ = plant sample (Calotropis gigantean)
}

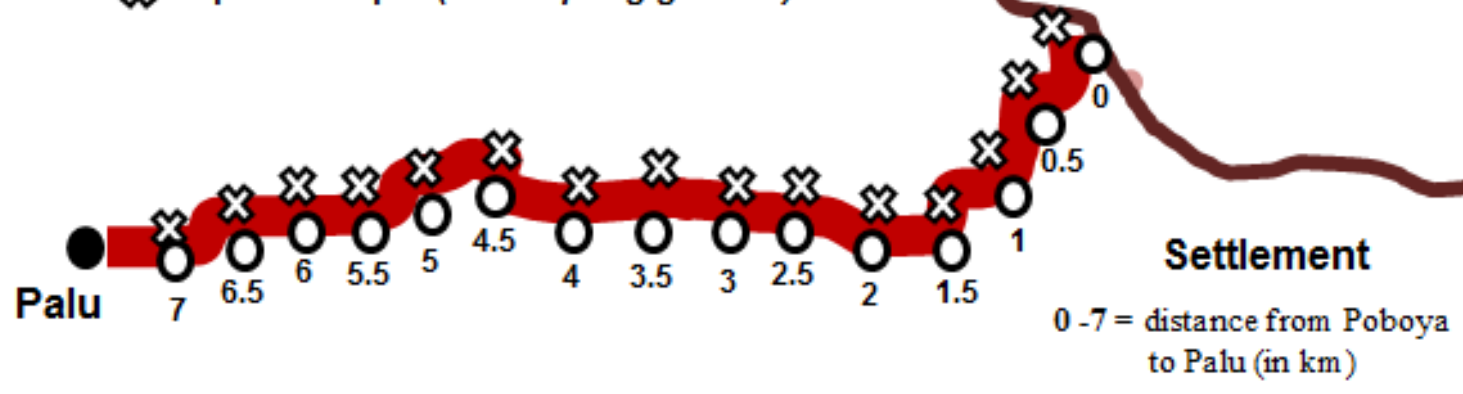

Figure 2. Sampling Points

\subsection{Mercury Analysis}

\subsubsection{Analytical method for measuring total mercury levels in soil and plant}

This research used cold vapor atomic absorption spectrometry (CVAAS) to determine the total mercury in soil. In principle, this method will reduce $\mathrm{Hg}^{2+}$ ions in the soil sample, and generate $\mathrm{Hg}^{0}$ using stannous chloride, then it measures the absorbance by introducing $\mathrm{Hg}^{0}$ into the photo-absorption cells. The test procedures for the soil samples followed the mercury analysis manual as set by the Japanese Ministry of the Environment [20]. There were several treatments undertaken to analyze the soil samples, which included the addition of $1 \mathrm{ml}$ of distilled water, $2 \mathrm{ml}$ of $\mathrm{HNO}_{3}-\mathrm{HClO}_{4}(1+1)$, and $5 \mathrm{ml}$ of $\mathrm{H}_{2} \mathrm{SO}_{4}$ in a maximum 500 $\mathrm{mg}$ of soil wet weight in a flask, then heated for 30 minutes at $200-230^{\circ} \mathrm{C}$ on a hot plate, then mercury was extracted. After cooling down for a few minutes, the solution was diluted with distilled water using up to $50 \mathrm{ml}$. Only a $5 \mathrm{ml}$ solution was analyzed using Mercury RA-3 (RA-3, NIC Company). This was repeated three times for each soil sample for the purposes of accuracy. For comparison, we used the measured human hair standard from National Institute of Environmental Studies Japan, where the value was 3.95 $\mathrm{ng} / \mathrm{mg}$.

A similar analysis was used for both soil samples and plant samples. The plant samples were analyzed using a CVAAS system. The plant samples were cleaned and rinsed several times, dried at $40^{\circ} \mathrm{C}$ for 24 hours and finely chopped, before laboratory analysis. The same treatments were used as in the soil samples analysis, where less than $500 \mathrm{mg}$ of plant sample was balanced for analyzing. The relation of mercury concentration in soil and plant can be determined by transfer factor. The transfer factor is a calculation to know the distribution of total mercury in soil to plant. Where, the equation of transfer factor is a division of the total mercury in plant by the total mercury in soil Mahmood and Malik [44].
2.3.2. Analytical method for measuring the total carbon and nitrogen in soil

As a reference, this research analyzed concentration of nitrogen and carbon in soil samples using an $\mathrm{NC}$ coder (SUMIGRAPH NCH-22A, Sumika Chemical Analysis Service Ltd, Japan). This NC coder is a semi-automatic device that uses the oxygen circulating combustion system.

\subsubsection{Pollution Index (Pi)}

Related to the maximum standard of total mercury in soil, and the total mercury concentration in the research area, we assess the pollution index (Pi), where the concentration of total mercury in soil is divided by the respective total mercury standards set in Japan $(0.2 \mathrm{ng} / \mathrm{mg})[32,33]$. The results categorize into five pollution levels:

$$
\begin{array}{cc}
P i \leq 0.7=\text { excellent } & P i \leq 3.0=\text { pollution } \\
P i \leq 1.0=\text { safe } & P i \geq 3.0=\text { heavily polluted } \\
P i \leq 2.0=\text { lightlypolluted } & F u \text { and Guilan }[48]
\end{array}
$$

\section{Results}

\subsection{Mercury in Soil}

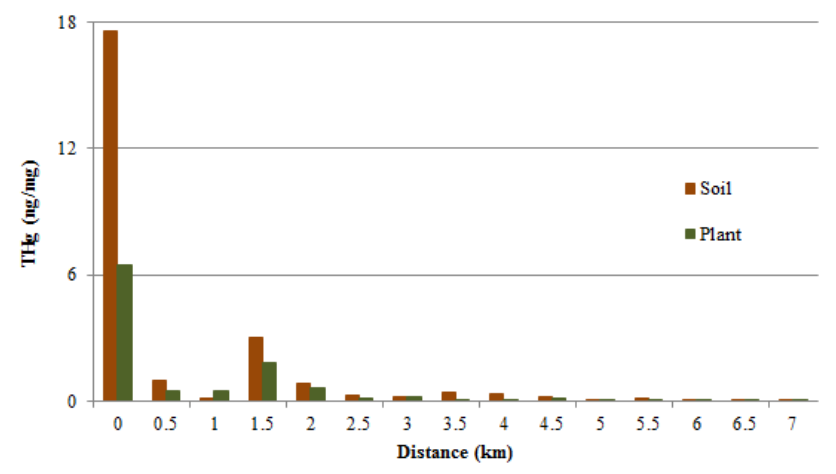

Figure 3. Total mercury concentration in soil and plant

Soil is one of the media used to monitor the concentration 
of mercury in the environment. Mercury in the atmosphere from amalgamation burning deposits in the top layer of soil. Top soil was used to analyze the total mercury in this research and total mercury in soil decreased from the top layer to the bottom layer vertically Santos-Francés [5].

The results show in figure 3 that the total mercury in soil had a range from $0.04-17.62 \mathrm{ng} / \mathrm{mg}$ within $7-0 \mathrm{~km}$ distance to the mercury source (edge of the gold mining area). The highest concentration of mercury was at the edge of the gold mining area-i.e. $17.62 \mathrm{ng} / \mathrm{mg}$. It was higher than $0.2 \mathrm{ng} / \mathrm{mg}$, which is the level in general mercurial soil in Japan, Ministry of Environment [20]. Within 4.5-7 km, all of the concentrations became less than $0.2 \mathrm{ng} / \mathrm{mg}$. The mercury concentrations were $1 \mathrm{ng} / \mathrm{mg}$ and $3 \mathrm{ng} / \mathrm{mg}$ for $0.5 \mathrm{~km}$ and 1.5 $\mathrm{km}$, respectively, from the source, which was the second highest place. After $1 \mathrm{~km}$, it decreased to $0.1 \mathrm{ng} / \mathrm{mg}$.

Furthermore, plant is also one of the commonly used bio-indicators to enable monitoring in the level of mercury present in the environment Lodenius [49] and reports of Rasmussen et al[29] showed that the leaf contains the highest mercury concentration in vegetative structures. Calotropis gigantea was used as the plant sample to discover the total mercury concentration in Palu. The total mercury concentration in plant was in a range of $0.05-6.5 \mathrm{ng} / \mathrm{mg}$ at 0 up to $7 \mathrm{~km}$ (see Figure 3). The highest concentration was in the edge of gold mining area. The distance up to $1.5 \mathrm{~km}$ was $1.84 \mathrm{ng} / \mathrm{mg}$ of total mercury in plant and it decreased to 0.05 $\mathrm{ng} / \mathrm{mg}$.

\section{Discussion}

\subsection{Mercury in Soil}

Mercury concentration in Poboya's soils are above the mercury concentration in Brazil, which was in the range of $0.05-0.21 \mathrm{ng} / \mathrm{mg}$ Roulet et al [30]. Generally, the total mercury concentrations decrease as the distance to the gold mining area increases. A similar trend is also reported in Chongqing City, China, where soil mercury contents in the range of $0.0064-0.881 \mathrm{ng} / \mathrm{mg}$ at a distance of 0 up to $4 \mathrm{~km}$ from the gold mining area Wang et al [31].

The result (see table 1) reflected that the most affected area of mercury is at 0 up to $4 \mathrm{~km}$, where the pollution index showed heavy pollution levels for those distances. It verified the previous research, in that the high concentration of $\mathrm{Hg}(0)$ in atmosphere for a distance of less than $5 \mathrm{~km}$ away from Poboya, ranged from 2096 to $3299 \mathrm{ng} / \mathrm{m}^{-3}$ Nakazawa et al[26]. The total mercury concentration for 0 up to $4 \mathrm{~km}$ away from Poboya also indicated a higher soil mercury concentration than normal-i.e., $0.01-0.03 \mathrm{ng} / \mathrm{mg}[11,35]$.
Table 1. Pollution Index of total mercury concentration in soil

\begin{tabular}{|c|c|c|c|c|c|c|}
\hline $\begin{array}{c}\text { Dista } \\
\text { nce } \\
(\mathrm{km})\end{array}$ & $\begin{array}{c}\mathrm{THg} \\
\text { of } \\
\text { soil } \\
\text { (ng/ } \\
\mathrm{mg})\end{array}$ & $\mathrm{Pi}$ & $\begin{array}{c}\text { Pollution } \\
\text { level }\end{array}$ & $\begin{array}{c}\text { Total } \\
\text { Nitro } \\
\text { gen } \\
(\mathrm{mg} / \\
\mathrm{mg}- \\
\mathrm{N})\end{array}$ & $\begin{array}{c}\text { Total } \\
\text { Carbon } \\
(\mathrm{mg} / \mathrm{mg} \\
-\mathrm{C})\end{array}$ & $\begin{array}{c}\mathrm{THg} / \mathrm{carb} \\
\text { on } \\
\text { (ng-Hg/m } \\
\mathrm{g}-\mathrm{C})\end{array}$ \\
\hline 0 & 17.62 & $\begin{array}{c}88.0 \\
9\end{array}$ & $\begin{array}{l}\text { heavily } \\
\text { polluted }\end{array}$ & 0.05 & 0.81 & 21.813 \\
\hline 0.5 & 0.98 & 4.92 & $\begin{array}{c}\text { heavily } \\
\text { polluted }\end{array}$ & 0.09 & 1.42 & 0.694 \\
\hline 1 & 0.14 & 0.69 & excellent & 0.11 & 1.65 & 0.083 \\
\hline 1.5 & 2.99 & $\begin{array}{c}14.9 \\
5 \\
\end{array}$ & $\begin{array}{l}\text { heavily } \\
\text { polluted }\end{array}$ & 0.18 & 2.97 & 1.006 \\
\hline 2 & 0.85 & 4.27 & $\begin{array}{c}\text { heavily } \\
\text { polluted }\end{array}$ & 0.16 & 2.42 & 0.353 \\
\hline 2.5 & 0.27 & 1.36 & $\begin{array}{c}\text { lightly } \\
\text { polluted }\end{array}$ & 0.21 & 3.42 & 0.080 \\
\hline 3 & 0.18 & 0.88 & safe & 0.25 & 4.76 & 0.037 \\
\hline 3.5 & 0.44 & 2.21 & pollution & 0.70 & 10.12 & 0.044 \\
\hline 4 & 0.34 & 1.71 & $\begin{array}{c}\text { lightly } \\
\text { polluted }\end{array}$ & 0.40 & 6.72 & 0.051 \\
\hline 4.5 & 0.19 & 0.97 & safe & 0.77 & 8.86 & 0.022 \\
\hline 5 & 0.07 & 0.37 & excellent & 0.26 & 3.73 & 0.020 \\
\hline 5.5 & 0.14 & 0.68 & excellent & 0.81 & 8.57 & 0.016 \\
\hline 6 & 0.06 & 0.30 & excellent & 0.18 & 2.10 & 0.028 \\
\hline 6.5 & 0.05 & 0.24 & excellent & 0.43 & 6.67 & 0.007 \\
\hline 7 & 0.03 & 0.17 & excellent & 0.19 & 4.43 & 0.008 \\
\hline
\end{tabular}

The table above also shows that the highest total carbon was found at a distance of $3.5 \mathrm{~km}$ from the gold mining area (Poboya) and the highest total nitrogen was at a distance of $5.5 \mathrm{~km}$ from Poboya. The lowest carbon and nitrogen levels were found at the gold mining area (Poboya), with a rate of 0.8 and 0.05 , respectively.

Organic matters can be an influencing factor in the distribution of mercury in soil $\mathrm{Wu}$ et al[35]. Table 1 describes the total mercury concentration in soil per carbon. It showed that high mercurial soil contained low carbon level. The highest rate was found at the first point having 21.813 $\mathrm{ng}-\mathrm{Hg} / \mathrm{mg}-\mathrm{C}$ and gradually decreasing up to $1.5 \mathrm{~km}$ from the edge of the gold mining area. A further $2.5 \mathrm{~km}$ away, the total mercury per carbon in soil was shown to be gradually decreasing with an average of $0.03 \mathrm{ng}-\mathrm{Hg} / \mathrm{mg}-\mathrm{C}$. This was in the range of $0.007-0.08 \mathrm{ng}-\mathrm{Hg} / \mathrm{mg}-\mathrm{C}$. However, in this case the organic matters did not correlated with the concentration of $\mathrm{Hg}$ in soil. This result was verified by an obtained result in Göta River, Sweden, where $\mathrm{r}=0.4$ was identified between the organic matter and total $\mathrm{Hg}[36,37]$. It is depended on the quality of soil, such as the binding strength of $\mathrm{Hg}$ and $\mathrm{pH}$, rather than the organic matters contained in soil $[37,38,39]$. 


\subsection{Mercury Levels in Plant}

As expected, plant samples in Palu also followed a similar trend to that of the soil samples. Figure 3 illustrates that mercury concentration in plant was in a range of 0.05-6.5 $\mathrm{ng} / \mathrm{mg}$ at 0 up to $7 \mathrm{~km}$. As a comparison, mercurial plant data in Northwestern Ontario shows a similar range 0.035-0.0512 $\mathrm{ng} / \mathrm{mg}$ in 16 plant species Mailman and Bodaly[40]. Additionally, in the Usagre village, Almadén mining area and Idrija, the total mercury concentration is in the ranges of $0.057-37.6 \mathrm{ng} / \mathrm{mg}$ in 22 plant species Garcia-Sanchez et al[18], 0.45-43.7 ng/mg in 26 plant species Millán et al[41], and $0.21-51.8 \mathrm{ng} / \mathrm{mg}$ Garcia-Sanchez et al[18] respectively, which are almost higher than the mercury concentration in Palu. Nevertheless, all those data described a similar tendency with regard to distance and the mercury concentration in soil.

The data in Figure 3 clarified that the total mercury in soil was 2-9 times higher than the total mercury in plant. At the initial point $(0 \mathrm{~km})$ the total mercury in plant was $6.5 \mathrm{ng} / \mathrm{mg}$ while the total mercury in soil was twice that of mercury in plants. Based on statistical analysis, the total mercury concentration in soil has a strong correlation with total mercury concentration in plant, which is $r=0.98$ (see Figure 4). When the mercury concentration in the soil decreases, mercurial concentration in plant gradually decreases as well. However, some data showed a reverse relation. For example, at a distance of $1 \mathrm{~km}$ from the source (gold mining area) the total mercury concentration in plant was three times higher than in soil, which was $0.47 \mathrm{ng} / \mathrm{mg}$. This was caused by the mercurial atmosphere at these distances, less than $1 \mathrm{~km}$ from the edge of the gold mining area, that were extremely high according to an identification of mercury dispersion in Poboya, Palu Isrun[42] and also Calotropis gigantea (plant sample) is one of the taller plants therefore to volatilize from air through the leaves is more adequate than absorption from soil through roots Patra and Sharma[43].

The result assumed that the total mercury in plant was influenced by atmospheric factors. The transfer factor showed in range of 0.13-3.44, described in Table 2. Some studies reported that atmosphere is the most common mechanism for mercury absorption in plants Patra and Sharma[43]. Emitted mercury from amalgam burning is transmitted to the plant leaf via stomata or breathing apparatus $[5,10,18,19]$. Kotnik et al[16] found that the high concentrations of mercury in vegetation in the River Idrija resulted from 35,000 tons of mercury being released into the environment due to smelting processes. Other evidences were found in several cases, such as plant-tissues in moss and Rye grass that had absorbed mercury from air intensely and stably during the observation day within 8 days Lodenius et al [19]. De Temmerman[45] used leafy vegetables in order to compare mercury concentration in atmosphere. It was reported that the determination coefficient of regression between total gaseous mercury concentration in ambient air and mercury concentration in vegetables was $0.73-0.95 \mathrm{mg} / \mathrm{kg}$.

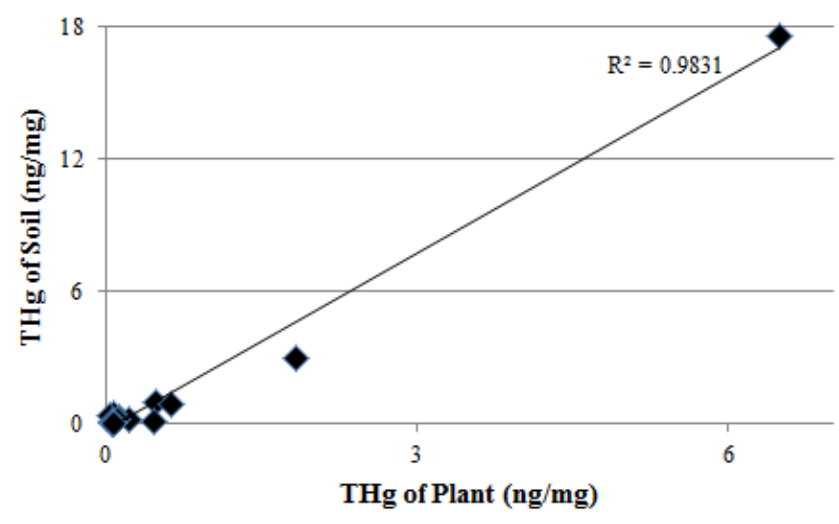

Figure 4. Correlation of $\mathrm{THg}$ in plant and $\mathrm{THg}$ in soil

Table 2. Transfer factor of total mercury concentration in soil and plant

\begin{tabular}{|c|c|}
\hline Distance (km) & Transfer Factor \\
\hline 0 & 0.37 \\
\hline 0.5 & 0.49 \\
\hline 1 & 3.44 \\
\hline 1.5 & 0.62 \\
\hline 2 & 0.74 \\
\hline 2.5 & 0.50 \\
\hline 3 & 1.26 \\
\hline 3.5 & 0.18 \\
\hline 4 & 0.13 \\
\hline 4.5 & 0.59 \\
\hline 5 & 0.82 \\
\hline 5.5 & 0.52 \\
\hline 6 & 0.91 \\
\hline 6.5 & 1.53 \\
\hline 7 & 2.11 \\
\hline & \\
\hline
\end{tabular}

In another possible way, mercury in soil is released to the leaf via the root system and distributed to all parts of the plant, including leaf mercury deposition Patra and Sharma[43]. However, the mercurial absorbance of the plant from soil through its roots is low. Some research showed that the mercury concentration in leaf was lower than soil. Zhang et al[46] reported $0.129-28.182 \mathrm{mg} / \mathrm{kg}$ and $0.001-2.673$ $\mathrm{mg} / \mathrm{kg}$ of mercury concentrations in soil and leaf, respectively. The highest mercury concentration in plant which accumulated in leaf is shown in data from the San Joaquín mining site, Mexico, which is $0.1-8.2 \mathrm{mg} / \mathrm{kg}$ Martínez-Trinidad[47]. This phenomenon occurred with the total mercury absorption in plant at a distance of between 0-7 $\mathrm{km}$ from the edge of the gold mining area to Palu. 


\section{Conclusions}

Results of this research obtained five important findings related with mercury affected area due to small-scale gold mining in Poboya. The findings are:

a) The mercury concentration in the soil decreases, when mercurial concentration in plant also gradually decreases at 0 up to $7 \mathrm{~km}$ away from the gold mining area,

b) Total mercury concentration in soil was in the range of $0.04-17.62 \mathrm{ng} / \mathrm{mg}$, which is 90 times higher than the commonly present soil in Japan,

c) The range of total mercury concentration in plant was $0.05-6.5 \mathrm{ng} / \mathrm{mg}$,

d) The transfer factor illustrated that the ratio was in range of 0.13-3.44,

e) Based on pollution level and soil samples, the mercurial affected area was within $4 \mathrm{~km}$.

\section{Acknowledgments}

The authors would like to thank the financial support provided by the Ministry of the Environment of Japan through the Environmental Research and Technology Development Fund (B1008); and gratefully acknowledge the tremendous contributions of the staffs in Tadulako University, Palu, Indonesia. We also thank to the community participation in study areas (Poboya and Palu) during the field sampling.

\section{REFERENCES}

[1] Cairns, Elaine., Kavitharan T., Makshoof A., Muhammad Y., Irene C., Y. Huang., Julia L., Dave Y. (2011) Source, concentration, and distribution of elemental mercury in the athmosphere in Toronto, Canada. Env. Pollution. 159, 2003-2008. doi: 10.1016/j.envpol.2010.12.006

[2] Sarikaya, Sezgin., Ozgur K., Didem A., Asli C., Can A., Mustafa S. (2010) Acute mercury poisoning: a case report. BMC Emergency Medicine. 10:7 .http://www.biomedcentral. com/1471-227X/10/7

[3] Rothenberg, S.E., X. Du., Y-G. Zhu., J.A. Jay. (2007) The impact of sewage irrigation on the uptake of mercury in corn plants (Zea mays) from suburban Beijing. Env. Pollution. 149, 246-251. doi: 10.1016/j.envpol.2007.01.005

[4] Lin, Che-Jen., Simo O. P. (1999) The chemistry of atmospheric mercury: a review. Atmos. Env. 33, 2067-2079. PII: S1352-2310(98)00387-2

[5] Santos-Francés, F., A. García-Sánchez., P. Alonso-Rojo., F. Contreras., M. Adams. (2011) Distribution and mobility of mercury in soils of a gold mining region, Cuyuni river basin, Venezuela. Journal of Env. Management. 92, 1268-1276. doi: 10.1016/j.jenvman.2010.12.003

[6] Zhou, Zhao S., Shao J. W., Zhi M. Y. (2008) Biological detection and analysis of mercury toxicity to alfalfa (Medicago sativa) plants. Chemosphere. 70, 1500-1509. doi:10.1016/j.chemosphere.2007.08.028

[7] Han, Fengxiang X., Yi S., David L. M., Charles A. W., M. John P. (2006) Binding, distribution, and plant uptake of mercury in a soil from Oak Ridge, Tennessee, USA. Science of the Total Env. 368, 753-768. doi: 10.1016/j.scitotenv.2006.02.026

[8] Gosar, Mateja., Simon P., Robert Š., Milan B., Nikolaj R. M., Sergej E. S. (1997) Distribution of mercury in the atmosphere over Idrija, Slovenia. Env. Geochemistry and Health. 19, $101-110$

[9] Mason, R. P., W. F. Fitzgerald., F. M. M. Morel. (1994) The biogeochemical cycling of elemental mercury: Anthropogenic influences. Geochimica et Cosmochimica Acta. 58:15, 3191-3198. doi:10.1016/0016-7037(94)90046-9

[10] Liu, Fei., Hangxin C., Ke Y., Chuandong Z., Yinghan L., Min P., Kuo L. (2014) Characteristics and influencing factors of mercury exchange flux between soil and air in Guangzhou City. Journal of Geochemical Exploration. 139, 115-121. http://dx.doi.org/10.1016/j.gexplo.2013.09.005

[11] Terán-Mita, Tania A., Angel F., Flor S., Joselito M. A., Jose A. A. (2013) High altitude artisanal small-scale gold mines are hot spots for Mercury in soils and plants. Env. Pollution. 173 , 103-109. http://dx.doi.org/10.1016/j.envpol.2012.10.008

[12] Pacyna, Elisabeth G., Jozef M. P., Frits S., Simon W. (2006) Global anthropogenic mercury emission inventory for 2000 . Atmos. Env. 40, 4048-4063. doi: 10.1016/j.atmosenv.2006.0 3.041

[13] Spiegel, Samuel J., Marcello M. V. (2010) International guidelines on mercury management in small-scale gold mining. Journal of Cleaner Production. 18, 375-385. doi: 10. 1016/j.jclepro.2009.10.020

[14] Telmer, Kevin., M.M. Veiga. (2008) World emissions of mercury from small scale and artisanal gold mining and the knowledge gaps about them. Canada. University of Victoria.

[15] Veiga, Marcello M., Peter A. M., Lars D. H. (2006) Origin and consumption of mercury in small-scale gold mining. Journal ofCleaner Production. 14, 436-447. doi: 10.1016/j.jc lepro.2004.08.010

[16] Kotnik, Jože., Milena H., Tatjana D. (2005) Current and past mercury distribution in air over the Idrija $\mathrm{Hg}$ mine region, Slovenia. Atmos. Env. 39, 7570-7579. doi: 10.1016/j.atmose nv.2005.06.061

[17] Xu, J., Andrea G. Bravo., Anders L., Stefan B., Rolf S., Jurate K. (2015) Sources and remediation techniques for mercury contaminated soil. Env. International. 74, 42-53. http://dx.doi.org/10.1016/j.envint.2014.09.007

[18] García-Sánchez, A., A. Murciego., E. Álvarez-Ayuso., I. Santa R., M.A. Rodríguez-González. (2009) Mercury in soils and plants in an abandoned cinnabar mining area (SW Spain). Journal of Hazardous Materials. 168, 1319-1324. doi: 10.1016/j.jhazmat.2009.03.009

[19] Lodenius, M., E. Tulisalo., A. Soltanpour-Gargari. (2003) Exchange of mercury between atmosphere and vegetation under contaminated conditions. The Science of the Total Env. 304, 169-174. doi:10.1016/S0048-9697(02)00566-1 
[20] Ministry of the Environment. (2004) Mercury Analysis Manual. Japan

[21] United Nations Environment Programme., Santoso B., Rosliana., Indonesia Environment Ministry. Mercury problems and national policies. Regional awareness-raising workshop on mercury pollution: a global problem that needs to be addressed. Bangkok. Thailand

[22] Iqbal, R., Takanobu Inoue. (2011) Mercury pollution in Java island: past and present. Ecotechnology Research. 16:2, $51-57$

[23] Sharma, B., K., 2007. Environmental Chemistry. Retrieved from https://books.google.co.jp

[24] Veiga, Marcello M. (2003) Information about the Project Sites in Indonesia (North Sulawesi and Kalimantan). Report to GEF/UNDP/UNIDO Global Mercury Project. www.globalmercury.org

[25] Boening, Dean W. (2000). Ecological effect, transport, and fate of mercury: a general review. Chemosphere. 40, 1335-1351. PII:S0045-6535(99)00283-0

[26] Nakazawa, K., Nagafuchi, O., Kawakami, T., Inoue, T., Yokota, K., Serikawa, Y., Cyio, B., Elvince, R. (2016) Human health risk assessment of mercury vapor around artisanal small-scale gold mining area, Palu city, Central Sulawesi, Indonesia. Ecotoxicology and Environ. Safety. 124, 155-162. http://dx.doi.org/10.1016/j.ecoenv.2015.09.042

[27] Ismawati, Yuyun., Jindrich P., Joe D. (2013) Titik Rawan Merkuri di Indonesia. [Mercury Hotspots in Indonesia]. BaliFokus. Denpasar

[28] Albasar, Muh. Ikhsan., Anwar D., Ida Leida M. (2013) Mercury $(\mathrm{Hg})$ exposure the community in distric Poboya of Palu Central Sulawesi. Hasanuddin University. Makassar

[29] Rasmussen, Pat E., Greg M., Jerome O. N. (1991) The analysis of vegetation for total mercury. Water, Air, and Soil Pollution. 56, 379-390

[30] Roulet, M., M. Lucotte., A. Saint-Aubin., S. Tran., I. Rhéault., N. Farella., E. De Jesus Da silva., J. Dezencourt., C.-J. Sousa P., G. Santos S., J. -R. D. Guimarães., D. Mergler., M. Amorim. (1998) The geochemistry of mercury in central Amazonian soils developed on the Alter-do-Chão formation of the lower Tapajós River Valley, Pará state, Brazil. The Science of the Total Env. 223, 1-24. PII: S0048-9697(98)00265-4

[31] Wang, Dingyong., Xiaojun S., Shiqiang W. (2003) Accumulation and transformation of atmospheric mercury in soil. The Science of the Total Environment. 304, 209-214. PII: S0048-9697(02)00569-7

[32] Esterhuizen, L., Fossey, A., Potgieter, E. (2012) Pollution index for dairy farm borehole water quality in the free state, South Africa. Water SA. vol. 38, 5

[33] Wang, X., Li, Y., Li, B., Dong, Z., Qu, L., Gao, Y., Chai, Z. (2011) Multielemental contents of foodstuffs from the Wanshan (China) mercury mining area and the potential health risks. Applied Geochemistry. 26, 182-187. doi: 10.1016/j.apgeochem.2010.11.017

[34] Senesi, Giorgio S., G. Baldassarre., N. Senesi., B. Radina. (1999) Trace element inputs into soils by anthropogenic activities and implications for human health. Chemosphere.

\section{9:2, 343-377. PII: s0045-6535(99)00115-0}

[35] Wu, F., Xu, L., Liao, H., Guo, F., Zhao, X., Giesy, J.P. (2013) Relationship between mercury and organic carbon in sediment cores from Lakes Qinghai and Chenghai, China. J Soils Sediments. 13, 1084-1092. doi: 10.1007/s11368-013-0 694-2

[36] Chen, J., Chakravarty, P., Davidson, G.R., Wren, D.G., Locke, M.A., Zhou, Y., Brown, G.Jr., Cizdziel, J.V. (2015) Simulta neous determination of mercury and organic carbon in sediment and soils using a direct mercury analyzer based on thermal decomposition-atomic absorption spectrophotometry. Analytica Chimica Acta. 871, 9-17.http://dx.doi.org/10.1016 /j.aca.2015.03.011

[37] Xu, J., Kleja, D.B., Biester, H., Lagerkvist, A., Kumpiene, J. (2014) Influence of particle size distribution, organic carbon, $\mathrm{pH}$ and chlorides on washing of mercury contaminated soil. Chemosphere. 109, 99-105. http://dx.doi.org/10.1016/j.chem osphere.2014.02.058

[38] Nordic Council of Miniters., (1992:3). Mercury in soil-distribution, speciation, and biological effects. Retrieved from http://books.googleusercontent.com/books/content

[39] New Jersey Department of Environmental Protection and Energy. (1995) Adsorption/desorption and transport of mercury and arsenic in New Jersey soils. Final Report. New Jersey

[40] Mailman, M., R.A. Bodaly. (2005) Total mercury, methyl mercury, and carbon in fresh and burned plants and soil in Northwestern Ontario. Env. Pollution. 138, 161-166. doi: 10.1016/j.envpol.2005.02.005

[41] Millán, R., R. Gamarra., T. Schmid., M.J. Sierra., A.J. Quejido., D.M. Sánchez., A.I. Cardona., M. Fernández., R. Vera. (2006) Mercury content in vegetation and soils of the Almadén mining area (Spain). Science of the Total Env. 368, 79-87. doi: 10.1016/j.scitotenv.2005.09.096

[42] Isrun. (2014) Perubahan aktivitas merkuri (Hg2+) tanah dan tanaman akibat pemberian kompos Tithonia diversifolia serta persebarannya di areal pengolahan emas Poboya Kota Palu. [The Changing and Spreading of Mercury $(\mathrm{Hg} 2+)$ in Soil and Plant (Tithonia diversifolia) due to Compost Addition in Gold Mining Area, Poboya, Palu City]. Unpublished Doctoral Thesis. Universitas Tadulako. Palu. Indonesia

[43] Patra, Manomita., Archana S. (2000) Mercury Toxicity in Plants. The Botanical Review. 66, 379-422

[44] Mahmood, A., and Malik, R.N. (2014) Human health risk assessment of heavy metals via consumption of contaminated vegetables collected from different irrigation sources in Lahore, Pakistan. Arabian Journal of Chemistry. 7, 91-99. http://dx.doi.org/10.1016/j.arabjc.2013.07.002

[45] De Temmerman, Ludwig., Nadia W., Natacha C., Edward R. (2009) Comparison of concentrations of mercury in ambient air to its accumulation by leafy vegetables: An important step in terrestrial food chain analysis. Env. Pollution. 157, 1337-1341. doi: 10.1016/j.envpol.2008.11.035

[46] Zhang, Zhongsheng., Qichao W., Dongmei Z., Na Z., Xianguo L. (2010) Mercury distribution and bioaccumulation up the soil-plant-grasshopper-spider food chain in Huludao City, China. Journal of Env. Science. 22:8, 1179-1183. doi:10.1016/S1001-0742(09)60235-7 
[47] Martínez-Trinidad, Sergio., Gilberto H. S., Martha Elena R. I., Juventino M. R., Gregorio S. M., Sara S. V., Rocío G. M. (2013) Total mercury in terrestrial systems (air-soil-plant-water) at the mining region of San Joaquín, Queretaro, Mexico. Geofísica International. 52-1, 43-58. doi:10.1016/S0016-7169(13)71461-2
[48] Fu, W., and Guilan, M. (2013) The characters and health risk assessment of vegetable $\mathrm{Pb}$ in Jilin Suburb. Procedia Environ. Sci. 18, 221-226. doi: 10.1016/j.proenv.2013.04.028

[49] Lodenius, Martin. (2013) Use of plants for biomonitoring of airborne mercury in contaminated areas. Env. Research. 125, 113-123. http://dx.doi.org/10.1016/j.envres.2012.10.014 